Clay gyttja representing the lowermost $3 \mathrm{~cm}$ of organic sediments in lake with water level 7-8 $\mathrm{m}$ above sea level. North side of Kangerdluarssuk, $60^{\circ} 52^{\prime} \mathrm{N}, 45^{\circ} 57^{\prime} \mathrm{W}$.

\title{
References
}

Fredskild, B. 1969: A postglacial standard pollen diagram from Peary Land, North Greenland. Pollen Spores 11, 573-583.

Funder, S. in press: Holocene stratigraphy and vegetation history in the Scoresby Sund area, East Greenland. Bull. Grønlands geol. Unders. 129.

Weidick, A. 1976: $\mathrm{C}^{14}$ dating of Survey material carried out in 1975. Rapp. Grønlands geol. Unders. 80, 136-144.

Weidick, A. 1977: A reconnaissance of Quaternary deposits in northern Greenland. Rapp. Grønlands geol. Unders. 85, 21-24.

\section{Comments on radiocarbon dates from Northern Greenland made during 1977}

\section{Anker Weidick}

Radiocarbon dates have been made on material from nine areas in northern Greenland (fig. 40). The results are given in the compilation of $\mathrm{C}^{14}$ dates (see Weidick, this report). The dates from area 5 have been given earlier (Weidick, 1977b). Comments on their significance are given below.

\section{Interglacial-interstadial ages}

The dates of GGU 226427 A and GGU 226427 B from Olrik Fjord (> 33000 B.P. and $>37000$ B.P. respectively) seem to be clear indications of a formation of interglacial age. The moraine-like appearance of the deposit might indicate a subsequent glaciation although the conservation of the shells indicates little glacial treatment.

The Holocene marine inundation in Olrik Fjord reached $45 \pm 5 \mathrm{~m}$ above sea level and modified the interglacial sediment locally; a shell sample previously dated from the eastern flank of eastern Kûgssuaq delta in Olrik Fjord (GGU 166125, $18990 \pm 280$ B.P., Weidick, $1976 \mathrm{a}$ ) is from a site approximately $14 \mathrm{~km}$ east of the sites of GGU $226427 \mathrm{~A} \mathrm{\&} \mathrm{B)}$ ). This date might be based on a mixed shell assemblage of Holocene and interglacial age (cf. Weidick, 1976b). If so, the interglacial deposits must have a wide extent along the northern shores of Olrik Fjord, but in part have also been reworked in and overlain by Holocene marine deposits.

Another example of fluvio-marine redeposition of interglacial material is found at Børglum Elv delta, Peary Land. The occurrence was first described by Fredskild (1969) and has 


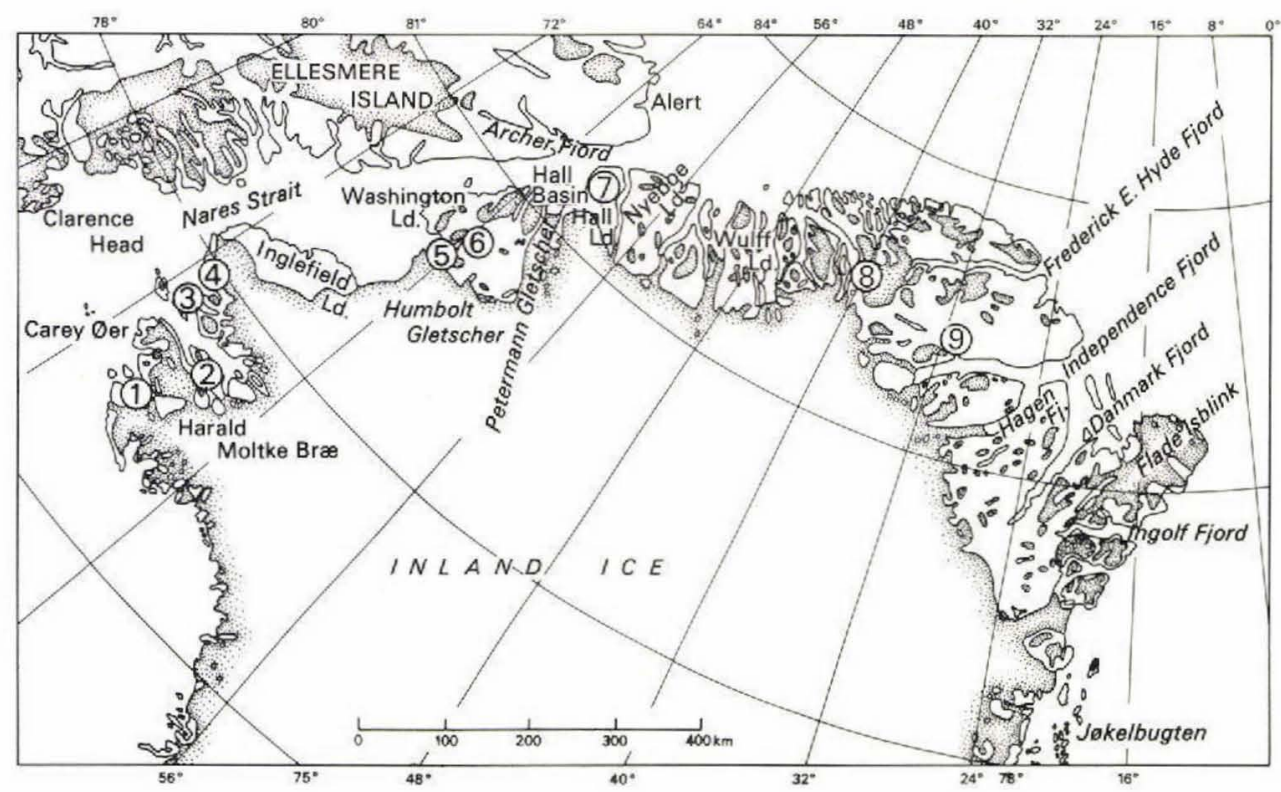

Fig. 40. Map of northern Greenland showing the areas from which radiocarbon age determinations are discussed by Weidick. 1: Thule Air Base - Narssârssuk - Chamberlin Gletscher; 2: Olrik Fjord; 3 : Herbert Ø; 4: Morris Jesup Gletscher; 5: Washington Land (GGU 212858-GGU 212973); 6: Washington Land (GGU 206054); 7: Hall Land; 8: J. P. Koch Fjord; 9: Børglum Elv, Peary Land.

been re-dated by GGU sample 226448 (> 35600 B.P.) in connection with an investigation of the formation age of the delta.

Wood of interglacial age from Washington Land (GGU 206054, > 51000 B.P.) found at an altitude of 260-245 m above sea level must be situated well above the Holocene marine limit. Although the marine limit in Washington Land is not exactly known, the figures of 73 $\mathrm{m}$ for Inglefield Land (Nichols, 1969) and of $108 \mathrm{~m}$ above sea level in Hall Land (Weidick, 1977a) suggest that the figure for Washington Land can hardly exceed $100 \mathrm{~m}$ by more than a few tens of metres, and glacial redeposition of this interglacial material is therefore suggested.

Wood seems to occur above the Holocene marine limit both at this interglacial locality in Washington Land and at a locality at Midsommersøerne, Peary Land, described earlier (Fredskild, 1969).

\section{Early Holocene ages}

The date from Narssârssuk (GGU 226454, 9385 B.P.) reveals an early deglaciation of the locality. The marine limit of the area is $37 \mathrm{~m}$ above sea level and the date must be referred to a relative sea level between this height and $12 \mathrm{~m}$ above sea level. There is agreement with 
earlier dates from the Thule Air Base area, indicating that the area was ice-free to its present extent as early as 9000-10 000 B.P. (Weidick, 1976b).

The neighbouring Olrik Fjord seems to have been deglaciated around 9000 years B.P. The oldest Holocene date of 8715 B.P. (GGU 226424) marks the beginning of the build-up of the great delta of eastern Kûgssuaq. The main deposition of the delta is related to relative sea levels between 45 and $35 \mathrm{~m}$ above sea level according to the dates this took place between approximately 8700 and 8200 B.P.

The building of eastern Kûgssuaq delta in Olrik Fjord is supposedly connected with the great fluviatile transport capacity of the river due to the shrinkage of the local ice cap between Olrik Fjord and Inglefield Bredning farther to the north.

The shell dates on the Holocene material collected by P. R. Dawes from eastern Kûgssuaq delta (Weidick, 1976b) fit into the pattern of the subsequent emergence of Olrik Fjord outlined in figure 41 .

In Hall Land, three new dates indicate an age for the marine limit $(108 \pm 2 \mathrm{~m}$ above sea level) at $9500-10000$ years B.P. These are:

GGU $2264419180 \pm 150$ B.P. at $85 \mathrm{~m}$ above sea level

GGU $2264409005 \pm 145$ B.P. at $80 \mathrm{~m}$ above sea level

GGU $2264468300 \pm 130$ B.P. at $55 \mathrm{~m}$ above sea level

Thus, the dates indicate a confirmation of the small Late Wisconsin extension of the Inland Ice over Hall Land, suggested by Davies (1972) and England (1976). This possibility of a restricted Wisconsin Inland Ice cover of Hall Land is also supported by the discovery by Dawes (1977) of moraines in northern Hall Land (Kap Ammen) caused by an ice cover over Ellesmere Island rather than by the Greenland Inland Ice. The relatively fresh forms of the Kap Ammen moraine might refer them to Wisconsin or even Late Wisconsin age. However, this last evidence contrasts with the assumption by England (1976) of a restricted Late Wisconsin ice cover also over Ellesmere Island.

According to the three dates the deglaciation of central Hall Land took place before or at 9500 B.P. which seems at variance with the date of 6100 B.P. (Davies, in Rubin \& Alexander, 1960) for the same locality at an altitude of $82 \mathrm{~m}$ above sea level. According to this date the deglaciation and early emergence of the areas close to the marine limit took place first at 6000-6500 B.P.

In Peary Land, the date of GGU 226451, 5700 B.P., indicates that the interior parts of J. P. Koch Fjord were ice-free at approximately 6000 B.P. (age of the marine limit at $45 \pm 5 \mathrm{~m}$ above sea level).

\section{Late Holocene development}

The radiocarbon dates from Herbert $\varnothing$ (GGU $212512 \&$ 212511) show that the island was ice-free long before 8500 B.P. and that emergence must have followed approximately the same trend as around Thule Air Base. The dates (8390 and 8345 B.P.) also indicate that the neighbouring Kingingneq glacier with its present front approximately $400 \mathrm{~m}$ from the locality has not expanded essentially since then although it is surrounded by neoglacial moraines.

Dates for neoglacial expansion are supplied by GGU 212655 from Morris Jesup Glet- 


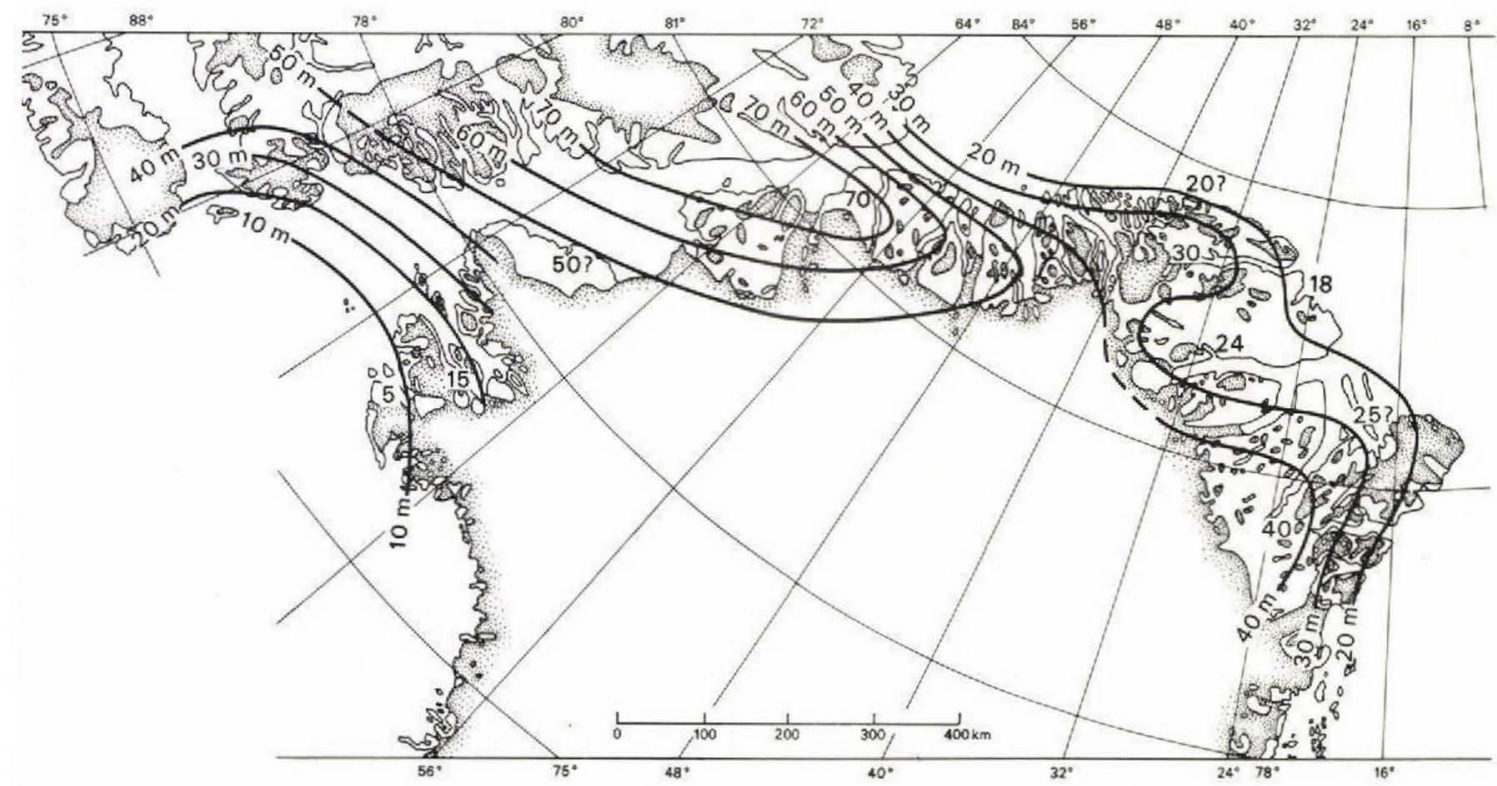

Fig. 41. Tentative minimum isobases at 6000 B.P. for North-West and North Greenland (Weidick, 1976b).

scher (650 B.P.) and by GGU 166678 (280 B.P.) and GGU 166679 (2650 B.P.) from Chamberlin Gletscher.

The presence of the relatively warm-loving species Chlamys islandicus in the sample from Morris Jesup Gletscher (Weidick, 1976b) is evidence of a slightly more northern extent of the species in Holocene time than hitherto suspected.

\section{Holocene emergence}

Figure 41 showing the tentative isobases for 6000 B.P. is only one of several suggestions (cf. England, 1976), since the scattered data can be interpreted in different ways. The model presented is essentially based on the concept that the main change of ice load between Late Wisconsin and the present day took place over Ellesmere Island rather than over the Greenland areas adjacent to the Nares Strait.

The new dates for the Thule area and for Peary Land do not essentially alter the picture presented in figure 41. In the Greenland areas closest to Ellesmere Island samples from marine terraces in Washington Land near to Humboldt Gletscher (Weidick, 1977b) gave:

GGU $2128586370 \pm 100$ B.P. at $55 \mathrm{~m}$ above sea level

GGU $2129735950 \pm 70$ B.P. at $50 \mathrm{~m}$ above sea level

which is near to the minimum value of approximately $60 \mathrm{~m}$ for 6000 B.P. given in figure 41 .

Hall Land is a special problem, since the three new dates (GGU 226440, 226446 \& 226446 ) imply a 6000 year B.P. isobase of around $25 \mathrm{~m}$ instead of the $70-80 \mathrm{~m}$ suggested by 
England (1976) and Weidick (1976b) on the basis of the 6100 B.P. date mentioned above. If so, the maximum zone of uplift will occur over Washington Land rather than over Hall Land. This would be in better agreement with expected relative ice thickness (former ice load) which would be greatest in the central parts of the straits between Ellesmere Island and Greenland. This however, does not explain the isolated young value (6100 B.P.) in Hall Land.

\section{Acknowledgements}

Thanks are due to Peter R. Dawes, Hans Jepsen and Niels Henriksen of GGU for the numerous collections of samples and observations in the field, and to Weston Blake (Geological Survey of Canada) for making possible the dating of samples in the GSC laboratory.

\section{References}

Davies, W. E. 1972: Landscape of Northern Greenland. Spec. Rep. Cold Reg. Res. Engng Lab. 164, 67 pp.

Dawes, P. R. 1977: Geological photo-interpretation of Hall Land: part of the regional topographical-geological mapping of northern Greenland. Rapp. Grønlands geol. Unders. 85, 25-30.

England, J. 1976: Postglacial isobases and uplift curves form the Canadian and Greenland High Arctic. Arctic Alp. Res. 8, 61-78.

Fredskild, B. 1969: A postglacial standard pollendiagram from Peary Land, North Greenland. Pollen Spores 11, 573-583.

Nichols, R. L. 1969: Geomorphology of Inglefield Land, North Greenland. Meddr Grønland 188,1, 109 pp.

Rubin, M. \& Alexander, C. 1960: U. S. Geological Survey radiocarbon dates V. Am. J. Sci. Radiocarbon Suppl. 2, 129-185.

Weidick, A. 1976a: $\mathrm{C}^{14}$ dating of Survey material carried out in 1975. Rapp. Gronlands geol. Unders. 80, 136-144.

Weidick, A. 1976b: Glaciations of North Greenland - New evidence. Polarforschung 46,1, 26-33.

Weidick, A. 1977a: A reconnaissance of Quaternary deposits in northern Greenland. Rapp. Grønlands geol. Unders. 85, 21-24.

Weidick, A. 1977b: $\mathrm{C}^{14}$ dating of Survey material carried out in 1976. Rapp. Grønlands geol. Unders. 85, 127-129. 